九州大学学術情報リポジトリ

Kyushu University Institutional Repository

\title{
A New Fluorometer to Detect Harmful Algal Bloom Species and its Application as a Long-Term HABs Monitoring Tool
}

YOSHIDA, Mitsuo

JFE Advantech Co., Ltd.

SHIMASAKI, Yohe i

Department of Bioresource Sciences, Faculty of Agriculture, Kyushu University

INOKUCHI, Daiki

Fisheries Research Institute, 0ita Prefectural Agriculture Forestry and Fisheries Research Center

NAKAZAT0, Ayahiro

Fisheries Research Institute, 0ita Prefectural Agriculture Forestry and Fisheries Research Center

他

https://doi.org/10.5109/4363549

出版情報: 九州大学大学院農学研究院紀要. 66 (1)，pp.37-43，2021-03-01. Faculty of Agriculture， Kyushu University

バージョン :

権利関係 : 


\title{
A New Fluorometer to Detect Harmful Algal Bloom Species and its Application as a Long-Term HABs Monitoring Tool
}

\author{
Mitsuo YOSHIDA ${ }^{1 *}$, Yohei SHIMASAKI, Daiki INOKUCHI ${ }^{2}$, Ayahiro NAKAZATO ${ }^{2}$, \\ Shusaku OTAKE ${ }^{3}$, Xuchun QIU ${ }^{4}$, Koki MUKAI, Herminio FOLONI-NETO ${ }^{1}$, Hiroharu KATO ${ }^{1}$, \\ Seiichiro HONDA ${ }^{1}$ and Yuji OSHIMA
}

\author{
Laboratory of Marine Environmental Science, Faculty of Agriculture, Kyushu University, \\ Fukuoka 819-0395, Japan \\ (Received October 30, 2020 and accepted November 4, 2020)
}

\begin{abstract}
Improving technology for monitoring of harmful algal species is an important issue in fisheries industries, coastal management, and public health agencies. We have studied the possibility of monitoring harmful algal species using specificity of chlorophyll fluorescence spectrum obtained through the investigation of fluorescence properties of various species. We found that the peak wavelengths of the chlorophyll fluorescence spectra of Karenia mikimotoi and Chattonella marina var. antiqua slightly shift towards longer wavelengths compared to other species. Based on these findings, we have developed an in situ Harmful Algal Indication sensor (HAI sensor), which measures the Fluorescence spectral Shift Index (FSI), which is defined as the ratio of fluorescence intensities at two different wavelengths $(670$ and $690 \mathrm{~nm})$ for representing the degree of fluorescence spectrum shifts, from the fluorescence intensities excited by blue light. The performance evaluation of HAI sensor for algal strains showed that FSI of Karenia mikimotoi and Chattonella marina var. antiqua were higher than those of other species. These results indicate that HAI sensor is able to detect these harmful algae. The field studies, conducted in Saiki Bay, Oita Japan in 2017, compared vertical profiles of FSI measured by HAI sensor with the species composition estimated by microscopic analysis. In these observations, HAI sensor successfully detected vertical distributions of Karenia mikimotoi. Furthermore, we have conducted long-term mooring observation using two units of HAI sensor, which were placed at mid and near-bottom layers and connected to a telemeter system in Saiki bay, Oita Japan in 2019. In this observation, HAI sensor detected the presence of Karenia mikimotoi at concentrations as low as 27 cells ml-1 $^{-1}$, suggesting that HAI sensor is useful for harmful algal blooms (HABs) monitoring and early warning systems.
\end{abstract}

Key words: Karenia mikimotoi, Chattonella marina, Fluorescence, Early warning system, HABs monitoring system

\section{INTRODUCTION}

Harmful Algal Blooms (HABs) can cause serious damage to fisheries and aquaculture industries. HABs produce a variety of toxins that cause heavy mortality of fish and other marine organisms during their bloom, which in turn can affect these organisms stocks and disrupt business activities (Furuya et al., 2018). In Asia, Karenia mikimotoi (Dinophyceae) and Chattonella marina var. antiqua (Raphidophyceae) are among the phytoplankton species that have caused severe damage frequently (Imai et al., 2006, 2012, Sakamoto et al., 2020), and because of that, their dynamics have been monitored daily (Sakamoto et al., 2020).

Currently, most of the HABs monitoring is done

1 JFE Advantech Co., Ltd., 3-48, Takahata-cho, Nishinomiya, Hyogo 663-8202, Japan

${ }^{2}$ Fisheries Research Institute, Oita Prefectural Agriculture Forestry and Fisheries Research Center, 194-6 Tsuiura, Kamiura, Saiki, Oita 879-2602, Japan

${ }^{3}$ Fisheries Section, Rural Community Promotion Department, Oita Prefecture Eastern Region Bureau, 786-1 Kunisaki-cho Ankokuji, Kunisaki, Oita 873-0504, Japan

${ }^{4}$ Institute of Environmental Health and Ecological Security, School of the Environment and Safety Engineering, Jiangsu University, Zhenjiang, Jiangsu 212013, PR China

* Corresponding author: e-mail: m-yoshida@jfe-advantech.co.jp (M. Yoshida) using discrete water sampling. These samples need to be transferred from the field to a laboratory to have the present phytoplankton species identified and counted using optical microscopy. However, this procedure is costly, time consuming, and not very accurate as it is highly manual oriented and requires high skilled personnel to identify target species (Yuan et al. 2012). Still, frequency and coverage of observations must be increased in order to improve accuracy, which is very difficult at current stage. Therefore, there is a need for new technologies that would allow enhancing monitoring coverage and efficiency in order to prevent or reduce the HABs economic impact.

There are many commercially available instruments that can measure chlorophyll fluorescence. Usually, the information obtained from these instruments is quite general and only allow us to infer about the total biomass, since information about phytoplankton groups or species cannot be obtained. However, there are more sophisticated fluorometers, such as those described in Beutler et al. (2002) and Yoshida et al. (2010) that make use of different wavelengths to excite the phytoplankton when measuring in vivo fluorescence. These instruments are able to separate phytoplankton in groups, but still, cannot separate them at species level. Therefore, these instruments are not adequate for continuous HABs monitoring, which requires species identification and 
concentration estimates. In fact, autonomous and continuous species identification at the current stage is still a challenge. There are works describing different strategies for automation and identification of phytoplankton species including harmful algae (Buskey and Hyatt, 2006; Olson and Sosik, 2007; Shapiro et al., 2015). However, as far as we know, these solutions involve a high costs and/or a significant level of complexity. A device that directly identify and estimates a particular species has yet to be developed.

In this study, we address these issues through the investigation of chlorophyll fluorescence properties of various species including $K$. mikimoto $i$ and C. marina var. antiqua and the development of a harmful plankton detection sensor making use of chlorophyll fluorescence characteristics. In addition, we have assessed the sensor performance using cultured species as well as profiling observations and a long-term mooring observation at sea.

\section{MATERIALS AND METHODS}

\section{Comparing algal strains using a fluorescence spec- trophotometer}

Algal strains shown in Table 1 were grown to stationary phase using modified SWM-3 medium (salinity 30, $\mathrm{pH}$ 7.9) in an incubator (at $25^{\circ} \mathrm{C}$, under $110 \mu \mathrm{mol}$ photons $\mathrm{m}^{-2} \mathrm{~s}^{-1}, 12: 12 \mathrm{~h}$ light:dark cycle). After that, while measuring the chlorophyll fluorescence intensity of the algal strains shown in Table 1 (No. 1 to 10) with the in vivo fluorometer (Model 10AU, Turner Designs, Inc., USA), a medium was added to the algal strain to prepare the chlorophyll fluorescence intensity of 100 to 200 approximately. Then these prepared cell suspensions were transferred to a glass cuvette and stirred and the fluorescence spectra were measured with a fluorescence spectrophotometer (Model F2700, Hitachi High-tech Science Corp., Japan). The fluorescence spectrophotometer excitation and emission bandpass were set to $5 \mathrm{~nm}$, and the fluorescence spectrum was measured at an excitation wavelength of $430 \mathrm{~nm}$ and a detection wavelength of 600 to $750 \mathrm{~nm}$. Fluorescence spectra were normalized at the detection wavelength of $675 \mathrm{~nm}$ to 1 and compared between species.

\section{Definition of Fluorescence spectral Shift Index (FSI)}

Fig. 1 shows the fluorescence spectrum of the algal strains measured by the fluorescence spectrophotometer normalized by the fluorescence intensity at a wavelength of $675 \mathrm{~nm}$. From Fig. 1, K. mikimotoi and C. marina var. antiqua had the highest fluorescence intensity at a wavelength of $680 \mathrm{~nm}$, while other species peaked at a wavelength of $675 \mathrm{~nm}$, denoting that K. mikimotoi and C. marina var. antiqua fluorescence spectra peaks were slightly shifted towards longer wavelengths when compared to other species.

In order to express and quantify such fluorescence spectra shift, we have developed the Fluorescence spectral Shift Index (FSI), which is the ratio of fluorescence intensity at $690 \mathrm{~nm}$ to that at $670 \mathrm{~nm}$ and can be define as follows,

$$
\text { FSI }=\frac{\text { Fluorescence intensity at } 690 \mathrm{~nm}}{\text { Fluorescence intensity at } 670 \mathrm{~nm}}
$$

We calculated the FSI for each algae strain as a proxy for the degree to which the peak of the fluorescence spectrum shifted towards longer wavelengths as shown in Fig. 2. We observed that C. marina var. antiqua FSI was equal to 1.01 while other species were in the range of 0.54 to 0.73 . Note that these FSI values were normalized by K. mikimotoi FSI.

\section{Development of the HAI sensor}

We have developed an underwater diffraction grating spectrophotometer in order to investigate phytoplankton fluorescence in the field (article under preparation). This prototype was developed focusing on exploring fluorescence properties in the field, and together with laboratory experiment data mentioned above, allowed us to build a low-cost sensor that focus on HABs monitoring and early warning systems, the Harmful Algal Indication sensor (HAI sensor).

The HAI sensor measures FSI in the field, and consequently, detects species in which the fluorescence spectrum peak is shifted, such as K. mikimotoi and C. marina var. antiqua. The instrument has fluores-

Table 1. Algal strains used in the comparison and characterization of fluorescence spectra for several algae and in the evaluation of the HAI sensor. The abbreviations (abbr.) described are used in the following figures

\begin{tabular}{llll}
\hline & \multicolumn{1}{c}{ Species } & \multicolumn{1}{c}{ Isolation region (strain) } & Abbr. \\
\hline 1 & Chattonella marina var. antiqua & Harima-nada, Japan (NIES-1) & Ca \\
2 & Heterosigma akashiwo & Hakata Bay, Japan & Ha \\
3 & Prorocentrum minimum & Hakata Bay, Japan & Km \\
4 & Karenia mikimotoi & Hakata Bay, Japan & Hc \\
5 & Heterocapsa circularisquama & Asoura Bay, Japan & Sm \\
6 & Skeletonema marinoi-dohrnii complex & Osaka Bay, Japan (NIES-324) & Sp \\
7 & Skeletonema pseudocostatum & Hakata Bay, Japan & Cm \\
8 & Chaetoceros muelleri & The north pacific, USA (CCMP 1316) & Cd \\
9 & Chaetoceros debilis & Hakata Bay, Japan & Ig \\
10 & Isochrysis galbana & English Channel Britanny Coast, France (NIES-2590) & Kmi \\
\hline
\end{tabular}




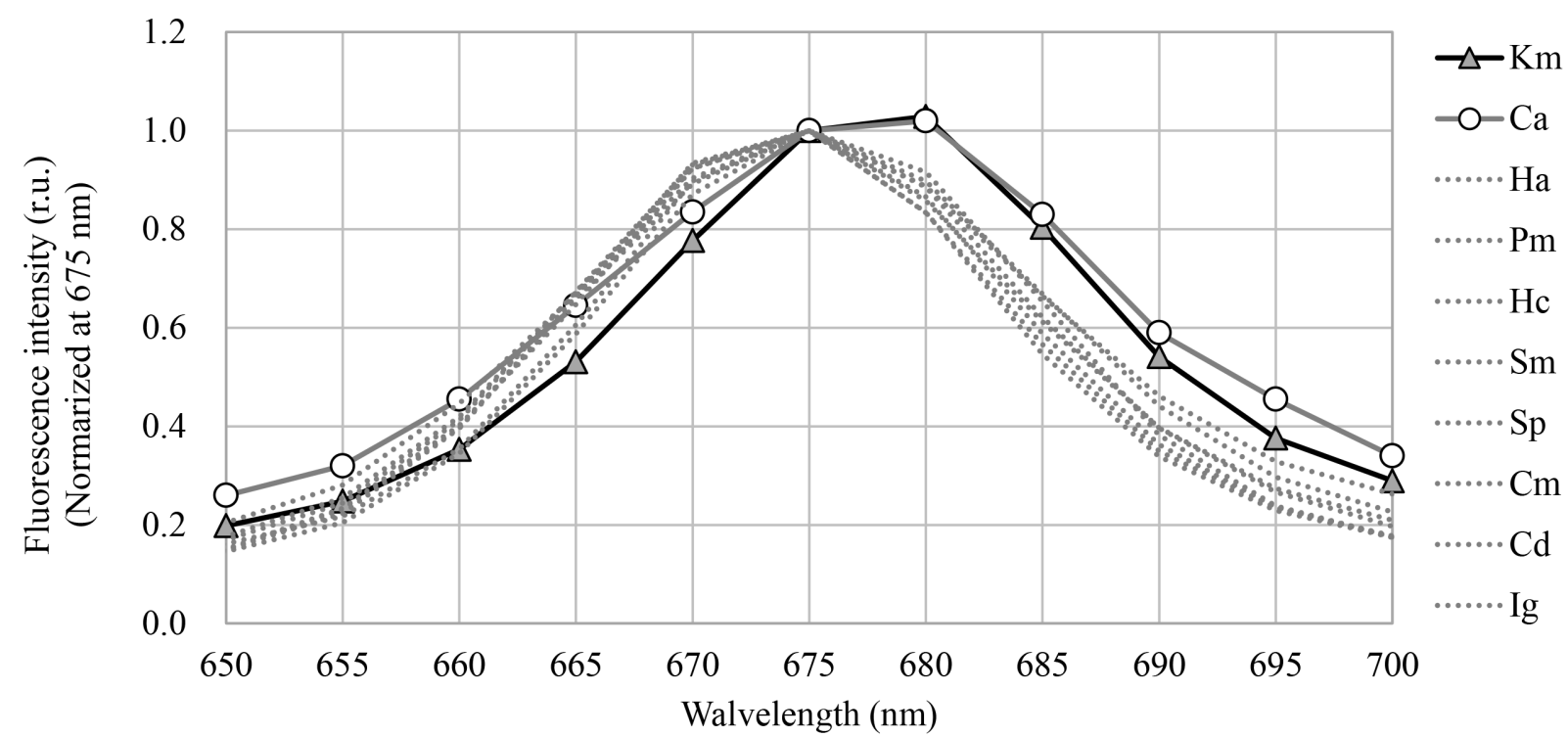

Fig. 1. Normalized fluorescence intensity spectra (with detection wavelength of $675 \mathrm{~nm}$ being 1) of several phytoplankton species. K. mikimotoi and C. marina var. antiqua are shown in solid line and other species shown in dashed line.

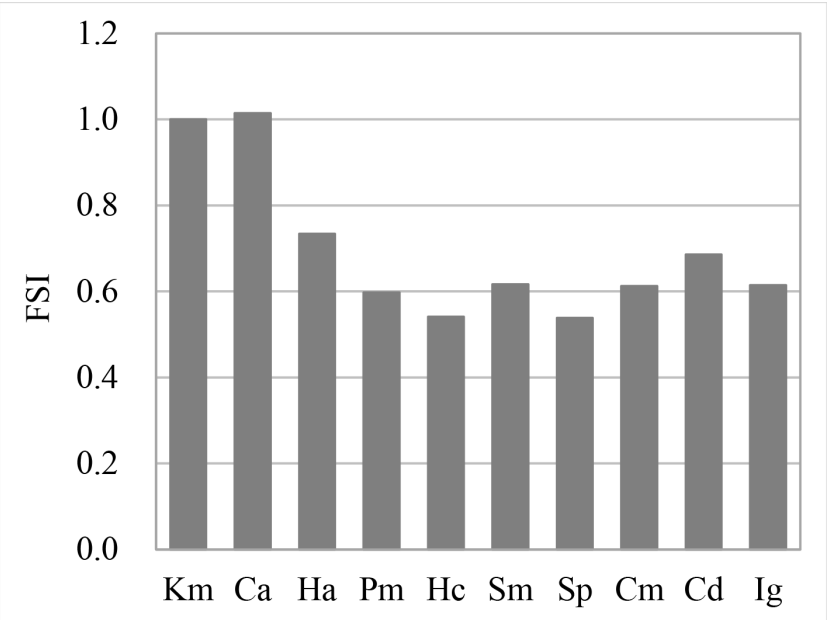

Fig. 2. FSI results for different species of phytoplankton. These results are normalized using $K$. mikimoto $i$ FSI results.

cence sensor with an excitation wavelength at $430 \mathrm{~nm}$ (Light Emitting Diode - LED) and measures fluorescence at $670 \mathrm{~nm}$ and $690 \mathrm{~nm}$ using bandpass optical filters. The instrument was designed to be small and light that can be deployed easily in the field. The HAI sensor configuration differs considerably from its prototype, since a diffraction grating spectrophotometer with sufficient wavelength resolution for analyzing emitted fluorescence, will be undoubtedly larger and heavier.

Fig. 3 shows the current available configurations of the HAI Sensor, with additional temperature and pressure sensor or an anti-fouling wiper for long-term observations. Power supply and communication are done via underwater cable and its hand-held processing unit or via integration with the mooring control system. The housing is made of titanium and it has $7 \mathrm{~cm}$ of diameter, $17.6 \mathrm{~cm}$ of length, and $0.8 \mathrm{~kg}$ of weight (in air).

\section{HAI sensor performance evaluation using algal strains}

We have verified the performance of the sensor using algal strains shown in Table 1 (No.1, 2, 5, 6 and 11). Cell density dilution series were prepared from the algal strain. Each sample was prepared by dispensing the algal strain with a micropipette into a black bucket filled with filtered seawater. The dimensions of the black bucket are $12.9 \mathrm{~cm}$ in diameter (12.3 cm inside diameter) and $20 \mathrm{~cm}$ in height $(19.7 \mathrm{~cm}$ inside). The sample was stirred with a glass rod carefully so as not to generate bubbles, and immediately after that, the HAI sensor was immersed at a constant height and performed measurements for about 1 minute. After the sensor measurements, the samples were counted for cell density using a microscope. The filtered seawater used to prepare the sample series emits a slight chlorophyll fluorescence. We assumed that this is due to chlorophyll contamination from cells destroyed during the filtration process. Therefore, before putting the algae strain in the black bucket, we measured only filtered seawater as a baseline to be subtracted from the sample series.

\section{Field experiment}

We carried out vertical profiling observations using the HAI sensor together with water sampling at the station A and B, in Saiki bay, Oita Japan (Fig. 4), from July to September 2017. In order to confirm the chlorophyll fluorescence intensity maximum, we conducted chlorophyll fluorescence intensity vertical profiling using a water quality profiler (Model AAQ175, JFE Advantech Co., Ltd., Japan). Surface seawater was collected with a bucket. At the station A, water was collected from depth of $2 \mathrm{~m}, 5 \mathrm{~m}$, at chlorophyll fluorescence intensity maximum and at the bottom (1 $\mathrm{m}$ above the bottom) with a water sampler (RIGO-B Transparent Water Bottle, Rigosha \& Co., Ltd., Saitama, Japan). At the sta- 


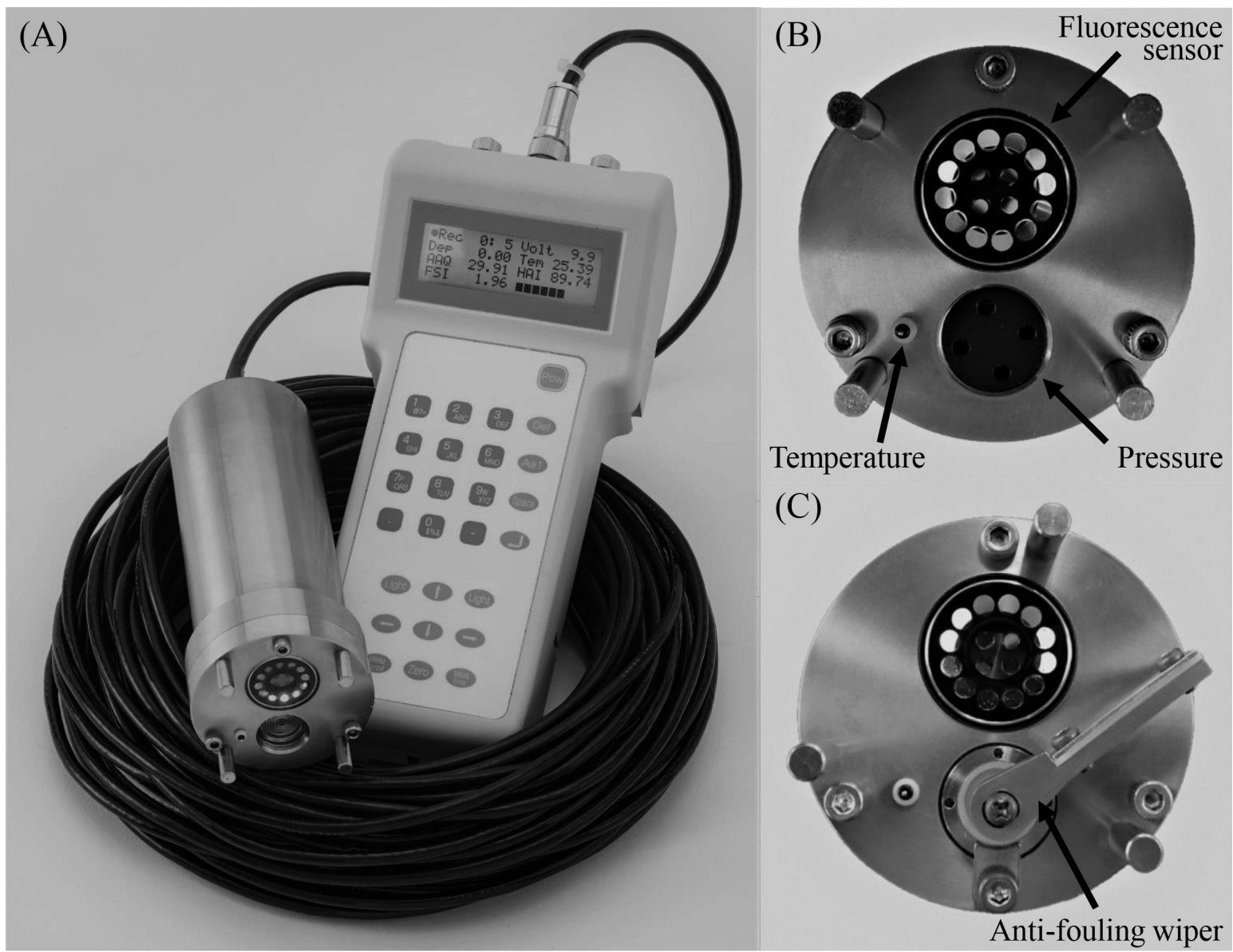

Fig. 3. Current available configurations of the HAI Sensor. (A) Overview of the HAI sensor (https://www.jfe-advantech.co.jp). We have the HAI sensor together with its hand-held processing unit and underwater cable. (B) We show all available sensors and their disposition and features. (C) Disposition of an anti-fouling wiper.

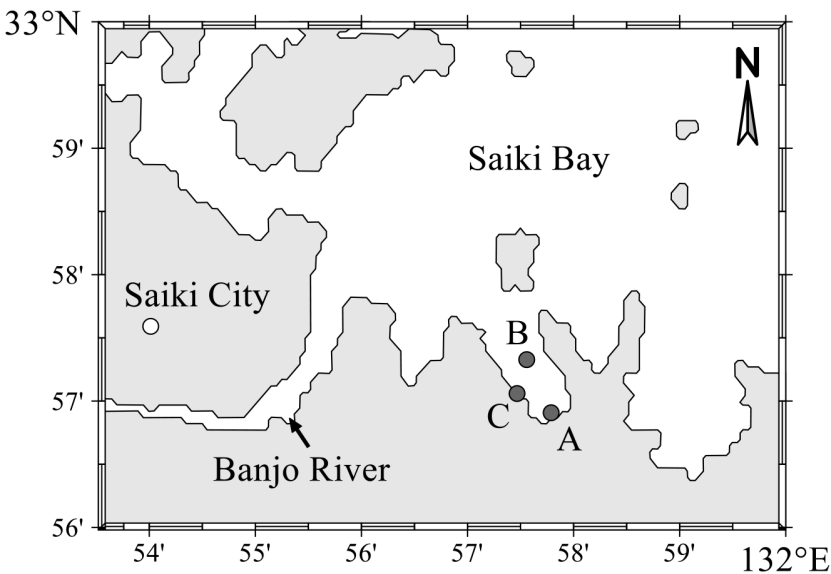

Fig. 4. The observation stations A $\left(32^{\circ} 56.907^{\prime} \mathrm{N}, 131^{\circ} 57.788^{\prime} \mathrm{E}\right)$, B ( $\left.32^{\circ} 57.328^{\prime} \mathrm{N}, 131^{\circ} 57.558^{\prime} \mathrm{E}\right)$, and $\mathrm{C}\left(32^{\circ} 57.059^{\prime} \mathrm{N}, 13^{\circ}\right.$ $\left.57.467^{\prime} \mathrm{E}\right)$ in the Saiki Bay, Oita Japan.

tion B, we collected water at the chlorophyll fluorescence intensity maximum depth using the water sampler. After water sampling, we performed vertical profiling observations using the HAI sensor (profiling speed of about $0.5 \mathrm{~m} \mathrm{~s}^{-1}$ ). The sampled water was brought to the laboratory on the same day, and had cell densities of K. mikimotoi, C. marina var. antiqua and Diatoms counted using a microscope. In addition, since the length of the water sampler was $0.7 \mathrm{~m}$, the measured results by the HAI sensor were averaged within $\pm 0.25 \mathrm{~m}$ every $0.5 \mathrm{~m}$ for evaluation.

\section{Long-term monitoring experiment}

Long-term continuous HABs monitoring test using the HAI sensor was performed at the station C, in Saiki bay, Oita Japan (Fig. 4), from April to September 2019. The sensor, equipped with an anti-fouling wiper, was moored and connected to a telemeter system (Model NITEBN, Nishimura Syokai Co., Ltd., Nagasaki, Japan) for a long-term deployment. Two units of the sensor were moored at the middle (depth of $6 \mathrm{~m}$ ) and at the bottom (1.5 $\mathrm{m}$ above the bottom) of the water column and performed observations at every 15 minutes. At every observation, the wiper first wipes the sensor surface, and then the sensors (at mid-water and near-bottom) measured 15 cycles alternately with 9 samples at $1 \mathrm{~s}$ interval each. A total of 135 measured values were obtained and averaged for each observation. Cell density analysis of K. mikimotoi, C. marina var. antiqua and Diatoms from the obtained water samples were carried out within the same day. 


\section{RESULTS}

\section{HAI sensor performance evaluations using algal strains}

Fig. 5 shows the FSI results from prepared samples measured with the HAI Sensor. The FSI of $K$. mikimoto $i$ showed values from 2.35 to 2.39 at cell densities of 4 cells $\mathrm{ml}^{-1}$ to 854 cells ml$^{-1}$, and the FSI of $C$. marina var. antiqua presented values from 2.08 to 2.15 at cell densities of 6

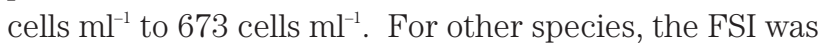
1.95 or less at all densities.

\section{Field experiment}

Fig. 6 shows the vertical profile of the measured FSI

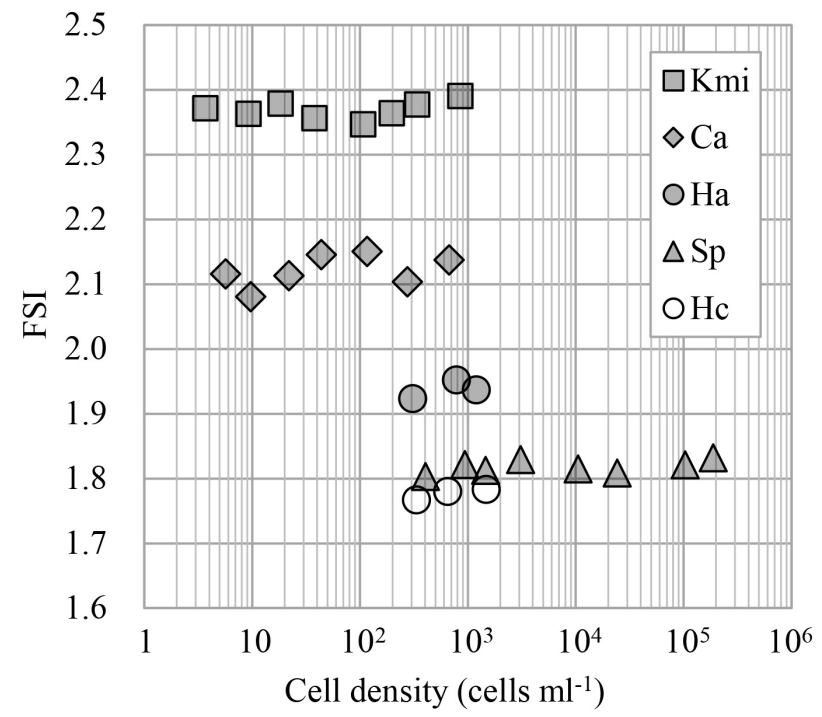

Fig. 5. FSI results for several algal strains in different cell density conditions.
(A) Cell Density (cells ml-1)

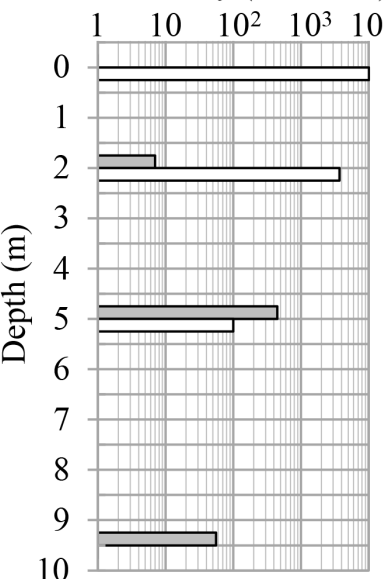

(B)

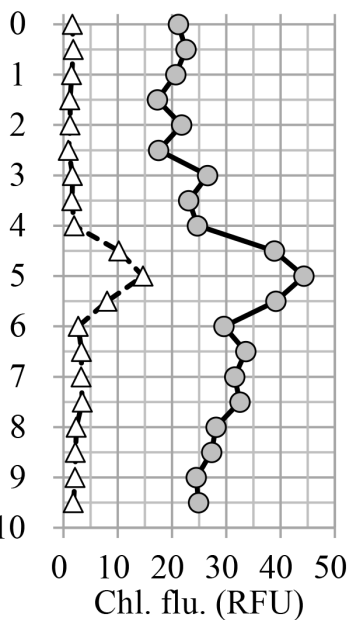

1.41 .61 .82 .02 .22 .4

Fig. 6. Microscopic analysis and vertical profiling done by the HAI sensor during a $K$. mikimoto $i$ HAB event on August $25^{\text {th }}$ 2017 at station A in Saiki bay, Oita, Japan (Fig. 4). (A) Cell densities estimated by microscopic analysis. Solid bars present $K$. mikimotoi, white bars present Diatoms. (B) FSI (circles) and chlorophyll fluorescence intensity (Chl. flu. - showed with triangles) vertical distribution obtained by the HAI sensor in relative fluorescence units (RFU). and chlorophyll fluorescence intensity and the results of microscopic analysis at the station A on August $25^{\text {th }} 2017$ during a $K$. mikimotoi red tide event in Saiki bay, Oita, Japan. The microscopic analysis results showed that at the surface, $2 \mathrm{~m}, 5 \mathrm{~m}$ and $9 \mathrm{~m}$ depth, the densities of K. mikimotoi were $0,7,450$ and 56 cells $\mathrm{ml}^{-1}$, respectively, and the densities of diatoms were 10100, 3700, 100 and 0 cells $\mathrm{ml}^{-1}$, respectively. On the other hand, the vertical profile measurement results with the HAI sensor showed that at the surface, $2 \mathrm{~m}, 5 \mathrm{~m}$ and $9 \mathrm{~m}$ depth, the FSI were $1.82,1.84,2.29$ and 1.90 , respectively, and the chlorophyll fluorescence intensity were 1.66, 1.25, 14.67 and 2.15 RFU (Relative Fluorescence Units), respectively. The FSI and chlorophyll fluorescence intensity maxima were found at $5 \mathrm{~m}$ as shown in Fig. 6, where the density of $K$. mikimoto $i$ was 450 cells $\mathrm{ml}^{-1}$. The maximum value of FSI reached around 2.35, which is the same value presented by the $K$. mikimoto $i$ algal strain we used in laboratory. Fig. 7 shows the vertical distribution of FSI and chlorophyll fluorescence intensity together with microscopic analysis results at station B on September $7^{\text {th }} 2017$ in Saiki bay, Oita, Japan. The microscopic analysis results showed that $K$. mikimotoi densities at surface and at $3 \mathrm{~m}$ depth, were both 0 cells $\mathrm{ml}^{-1}$, and diatoms densities were 5975 and 4200 cells $\mathrm{ml}^{-1}$, respectively. Whereas, the FSI obtained from the HAI sensor was equal to 1.81 and 1.70 at the surface and $3 \mathrm{~m}$ depth, respectively. The chlorophyll fluorescence intensities were 3.26 and $5.44 \mathrm{RFU}$ at the surface and $3 \mathrm{~m}$ depth, respectively. Fig. 7 also shows the chlorophyll fluorescence intensity maximum between 3 and $4 \mathrm{~m}$ depth. However, we did not observe a FSI maximum at this depth range.
(A)

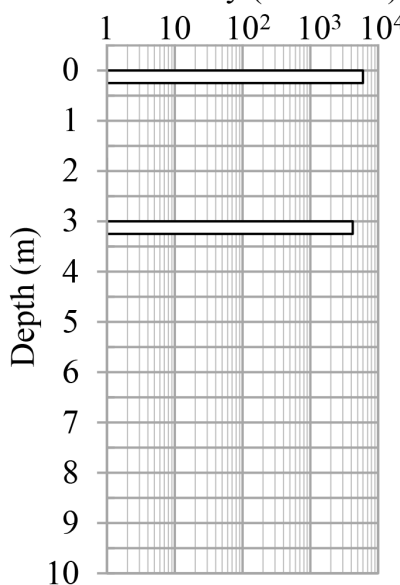

(B)

FSI

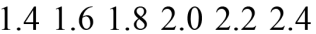

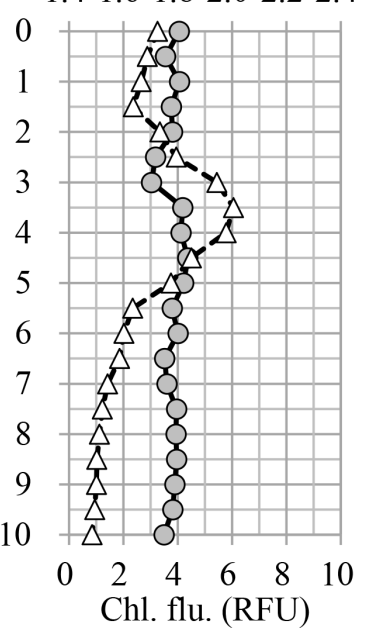

Fig. 7. Microscopic analysis and vertical profiling done by the $\mathrm{HAI}$ sensor during a HAB event (which $K$. mikimoto $i$ was not present) on September $7^{\text {th }} 2017$ at station B in Saiki bay, Oita, Japan (Fig. 4). (A) Cell densities estimated by microscopic analysis. Solid bars present $K$. mikimotoi, white bars present Diatoms. (B) FSI (circles) and chlorophyll fluorescence intensity (triangles) vertical distribution obtained by HAI sensor. 


\section{Long-term monitoring experiment}

Fig. 8 shows observation results obtained by the HAI sensors during a period of time in which $K$. mikimotoi cell density were higher than usual. The FSI time series obtained from the sensor placed at mid-water peaked at FSI equal to 2.12 during the period from 8:04 to 13:56 on August $9^{\text {th }}$ 2019. The FSI obtained from the near-bottom sensor showed values between 1.67 and 1.79 and did not form a clear peak during the same period of time. However, from 19:41 to 23:40 on August $9^{\text {th }} 2019$, the near-bottom sensor showed higher FSI values and peaking at FSI equal to 2.00, while the FSI measured at the mid water column was in the range of 1.81 to 1.91 and did not form a clear peak. In addition, water sampling and optical microscope analysis were carried out at 9:45 on August $9^{\text {th }}$ 2019 , and the results showed that $K$. mikimoto $i$ was present at cell densities of 27 cells $\mathrm{ml}^{-1}$ at mid-water, while diatoms were not present. At near-bottom, K. mikimotoi was present at cell densities of 27 cells $\mathrm{ml}^{-1}$ at midwater, while diatoms were not present. At near-bottom, K. mikimoto $i$ was still present at 1 cell $\mathrm{ml}^{-1}$ and diatoms remained inexistent.

\section{DISCUSSION}

Measuring the fluorescence spectra of the algal strains (Table 1) and comparing each spectrum (Fig. 1), we confirmed that the peak wavelength of the fluorescence spectra of $K$. mikimotoi and C. marina var. antiqua slightly shifts towards longer wavelengths compared to other species. Hence, we defined the FSI as a proxy for the degree of the fluorescence spectrum shift. We showed by using algal strains (Table 1) that the FSI of $K$. mikimotoi and C. marina var. antiqua are higher than those of other species (Fig. 2), which allowed us to use the FSI to infer about fluorescence spectrum shift and identify $K$. mikimoto $i$ and $C$. marina var. antiqua.
We have developed the Harmful Algal Indication sensor "HAI Sensor" that measures the FSI in the field. A simple spectroscopic method using optical filters allowed us to make a simple structure sensor that measures the fluorescence intensity at wavelength at $670 \mathrm{~nm}$ and $690 \mathrm{~nm}$. The instrument is compact and easily deployed in the field.

The performance of the HAI sensor was evaluated by measuring algal strains (Table 2) for several species and at different cell densities. As shown in Fig. 5, the FSI of $K$. mikimoto $i$ and $C$ marina var. antiqua was higher than other species and similar to those obtained using a fluorescence spectrophotometer. In addition, Fig. 5 shows that the HAI sensor can measure the FSI regardless of the cell density, since we obtained satisfactory results even when the density of $K$. mikimoto $i$ was 4 cell $\mathrm{ml}^{-1}$ or higher and $C$. marina var. antiqua was 6 cell $\mathrm{ml}^{-1}$ or higher.

From the profiling observations, we identified the chlorophyll fluorescence maximum at the same depth range of the FSI maximum observed using the HAI sensor (Fig. 6), which in turn suggests that chlorophyll fluorescence maximum is very likely caused by $K$. mikimotoi. On the other hand, in Fig. 7, the chlorophyll fluorescence intensity maximum could not be associated to FSI results (no clear maximum was identified). We assume that chlorophyll fluorescence intensity maximum at that time was caused by species other than $K$. mikimotoi or C. marina var. antiqua. Therefore, the HAI sensor allowed us to quickly identify if a chlorophyll fluorescence maximum is formed or not by $K$. mikimoto $i$ during vertical profiling the water column. This fact brings us new ways to approach HABs monitoring when compared to the tools currently available using conventional methods, such as the ability to quickly infer about spatial distribution of the species in question.

In the long-term continuous monitoring test, the

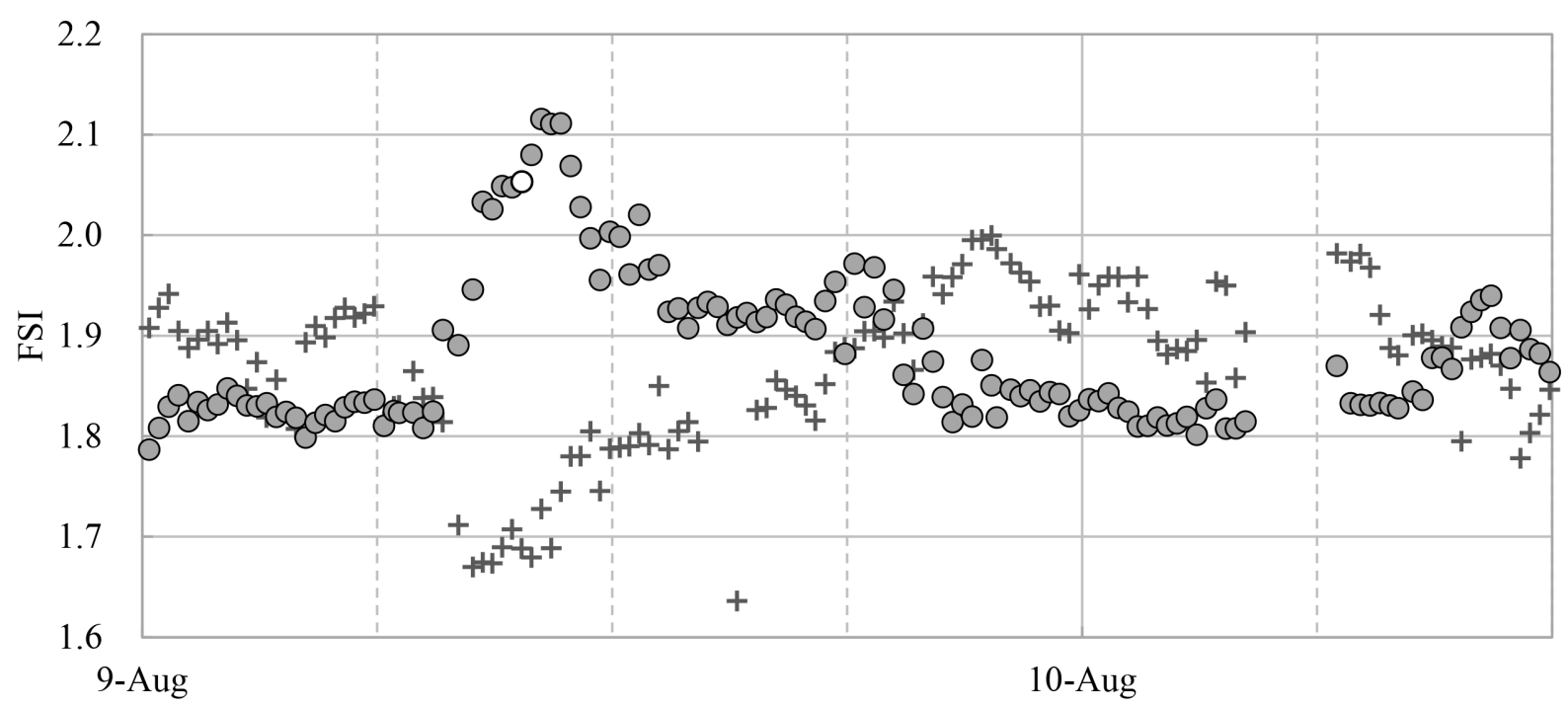

Days in August 2019

Fig. 8. FSI results from the long-term monitoring test of $K$. mikimotoi. The solid circles are FSI data at mid-water (6 m depth) and the pluses are FSI near the bottom (1.5 m above the bottom). The white circle is FSI at 9:41 9th August, which is close to the time

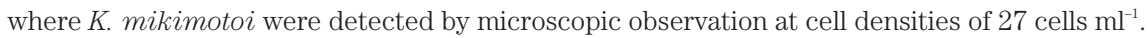


HAI sensors were moored at the middle and near-bottom of the water column considering the $K$. mikimoto $i$ diel vertical migration, which is described in the literature (Koizumi et al., 1996, Shikata et al., 2014, 2020). Although there were no large $K$. mikimotoi red tide events during the observed period, the FSI measured from the HAI sensor moored at mid-water exceed 2 on August $9^{\text {th }}$ 2019. On the same day, water sampling and microscopic analysis results showed $K$. mikimoto $i$ was indeed present (27 cells $\mathrm{ml}^{-1}$ ), which suggests that FSI obtained by the HAI sensor can identify $K$. mikimotoi even when its cell densities are not particularly high. In addition, the FSI diel variation observed at mid-water and near-bottom suggests that the HAI sensor was able to register $K$. mikimotoi diel vertical migration, which allow us not only to infer about the presence of this species but also about its dynamics. Our results show the potential of this new sensor in identifying and describing temporal and spatial distribution of K. mikimotoi, which is an important species for HABs monitoring in Asia (Furuya et al., 2018).

The HAI sensor showed a very satisfactory performance in our tests in Saiki Bay and has the potential to significantly reduce the operational costs involved in the monitoring of these two species. In the future, we will evaluate $C$. marina var. antiqua red tide events, and apply this new technique to HABs monitoring and early warning systems. We are also confident that the HAI sensor can be used to identify other harmful species that have similar traits, such as Karenia brevis and possibly other similar species. However, this still needs to be confirmed through field and laboratory experiments.

\section{AUTHOR CONTRIBUTIONS}

M. Yoshida designed the study, performed the laboratory experiments and the field observations, designed and manufactured the instrument, analyzed the data, and wrote the paper. Y. Shimasaki designed the study, performed the laboratory experiments and the field observations, cultured the algal strains, analyzed the data, and wrote the paper. D. Inokuchi, A. Nakazato and S. Otake performed the field observations and microscopic analyses, and maintained the instrument in the field. X. Qiu and K. Mukai performed the laboratory experiments and the field observations. H. Foloni-Neto analyzed the data and wrote the paper. H. Kato designed the study and analyzed the data, S. Honda designed the study, performed the laboratory experiments and the field observations, and analyzed the data.
Y. Oshima supervised the work, designed the study, analyzed the data, and wrote the paper. All authors assisted in editing of the manuscript and approved the final version.

\section{REFERENCES}

Beutler, M., K. H. Wiltshire, B. Meyer, C. Moldaenke, C. Lüring, M. Meyerhöfer, U.-P. Hansen and H. Dau, 2002 A fluorometric method for the differentiation of algal populations in vivo and in situ. Photosynthesis Research, 72: 39-53

Buskey, E. J. and C. J. Hyatt 2006 Use of the FlowCAM for semiautomated recognition and enumeration of red tide cells (Karenia brevis) in natural plankton samples. Harmful Algae, $\mathbf{5}(6)$ : $685-692$

Furuya, K., M. Iwataki, P. T. Lim, S. Lu, C.P. Leaw, R. V. Azanza, H.G. Kim 2018 Overview of harmful algal blooms in Asia. In "Global ecology and oceanography of harmful algal blooms", Ecological Studies 232, ed. by P.M. Glibert et al., Springer, Cham, pp 289-308

Imai, I., M. Yamaguchi and Y. Hori 2006 Eutrophication and occurrences of harmful algal blooms in the Seto Inland Sea, Japan. Plankton Benthos Res., 1(2): 71-84

Imai, I. and M. Yamaguchi 2012 Life cycle, physiology, ecology and red tide occurrences of the fish-killing raphidophyte Chattonella. Harmful Algae, 14: 46-70

Koizumi, Y., T. Uchida, and T. Honjo 1996 Diurnal vertical migration of Gymnodinium mikimotoi during a red tide in Hoketsu Bay, Japan. J. Plankton Res., 18: 289-294.

Olson, R. J. and H. M. Sosik 2007 A submersible imaging-in-flow instrument to analyze nano-and microplankton: Imaging FlowCytobot. Limnol. Oceanogr.: Methods, 5: 195-203

Sakamoto, S., W. A. Lim, D. Lu, X. Dai, T. Orlova, M. Iwataki 2020 Harmful algal blooms and associated fisheries damage in East Asia: Current status and trends in China, Japan, Korea and Russia. Harmful Algae, 101787

Shapiro, J., L. K. Dixon, O. M. Schofield, B. Kirkpatrick, G. J. Kirkpatrick 2015 Chapter 18 - New sensors for ocean observing: the optical phytoplankton discriminator. In "Coastal Ocean Observing Systems", ed. by Y. Liu et al., Academic Press, pp 326-350

Shikata T., S. Sakamoto, G. Onitsuka, K. Aoki and M. Yamaguichi 2014 Effects of salinity on diel vertical migration behavior in two red-tide algae, Chattonella antiqua and Karenia mikimotoi. Plankton Benthos Res., 9(1): 42-50

Shikata T., S. Kitatsuji, K. Abe, G. Onitsuka, T. Matsubara, N. Nakayama, K. Yuasa, Y. Nishiyama, K. Mizuno, T. Masuda and K. Nagai 2020 Vertical distribution of a harmful red-tide dinoflagellate, Karenia mikimotoi, at the decline stage of blooms. Journal of Sea Research, 165: 101960

Yoshida M., T. Horiuchi, and Y. Nagasawa 2011 In situ multiexcitation chlorophyll fluorometer for phytoplankton measurements: Technologies and applications beyond conventional fluorometers, in Proceedings of the OCEANS 2011 MTS/IEEE KONA

Yuan, J., T. Mi, Y. Zhen, Z. Yu 2012 Development of a rapid detection and quantification method of Karenia mikimotoi by real-time quantitative PCR. Harmful Algae, 17: 83-91 